\title{
PENINGKATAN PERILAKU KONSUMSI SAYUR DAN BUAH SEBAGAI UPAYA PENCEGAHAN OBESITAS PADA ANAK
}

\author{
Kristiawati $^{1}$, P.D. Rachmawati ${ }^{2}$, Y.S. Arief $^{3}$, I.D. Kurnia ${ }^{4}$, I. Krisnana ${ }^{5}$, E. Yunitasari ${ }^{6}$, \\ N.K.A. Armini ${ }^{7}$, M. Triharini ${ }^{8}$, R. Pradanie ${ }^{9}$, dan A.A. Nastiti ${ }^{10}$
}

\begin{abstract}
ABSTRAK
Penelitian menunjukkan bahwa angka kejadian obesitas pada anak usia sekolah di Indonesia cukup tinggi. Masalah ini disebabkan karena masih adanya persepsi orang tua bahwa anak yang gemuk adalah anak yang sehat serta konsumsi makanan yang rendah serat, namun upaya pencegahan dengan pendidikan kesehatan pada orang tua masih terbatas. Pengabdian kepada masyarakat ini bertujuan untuk memberikan pendidikan kesehatan tentang pentingnya konsumsi sayur dan buah sebagai upaya untuk pencegahan obesitas pada anak. Pendekatan yang digunakan dalam pengabdian masyarakat ini dengan pendidikan kesehatan metode modifikasi ceramah, demonstrasi dan simulasi oleh orang tua dalam menyiapkan sayur dan buah pada anak. Peserta pengabdian masyarakat ini adalah orang tua anak di SDN Mulyorejo I kelas tiga, sejumlah 28 orang tua. Evaluasi menggunakan lembar kuesioner pengetahuan, yang diberikan sebelum pendidikan kesehatan dan setelah pendidikan kesehatan. Hasil pengabdian masyarakat ini menunjukkan bahwa setelah pendidikan kesehatan peserta dengan pengetahuan baik meningkat dari $60.7 \%$ menjadi $96.4 \%$, dan tidak ada peserta dengan pengetahuan buruk setelah pendidikan kesehatan. Pengabdian masyarakat ini efektif untuk meningkatkan pengetahuan dan ketrampilan peserta tentang pentingnya konsumsi sayur dan buah, pengabdian masyarakat selanjutnya disarankan untuk memberikan pendidikan kesehatan tentang konsumsi sayur dan buah pada seluruh anak usia sekolah dan pada orang tua anak usia sekolah disemua kelas.
\end{abstract}

Kata kunci : sayur dan buah, anak usia sekolah, obesitas, pendidikan kesehatan, perilaku.

\begin{abstract}
The research shows that the number of obesity in the school-age children is quite high. This problem is caused by the perception of parent that overweight is healthy and school-age children over consump food that less of fiber, however the effort to prevent this problem by health education is limited. This public services aims to provide health education about the importance of consumption of vegetables and fruits as an effort to prevent obesity in children. The approach used in this community service was health education. The methods was lectures, demonstrations and simulations by parents in preparing vegetables and fruits in children. Participants of this public service were the parents of children in the primary school (SDN) of Mulyorejo I in the third grade, a number of parent were 28. The evaluation used a questionnaire of knowledge, provided before health education and after health education. The results of public service showed that after health education participants with good knowledge increased from $60.7 \%$ to $96.4 \%$, and no participants with poor knowledge after health education. This community service was effective to increase the knowledge and skills of participants about the importance of consumption of vegetables and fruits, further community service
\end{abstract}

${ }^{1}$ Staf Pengajar Fakultas Keperawatan Universitas Airlangga, kristiawati@fkp.unair.ac.id.
${ }^{2345678910}$ Staf Pengajar Fakultas Keperawatan Universitas Airlangga 
suggested to provide health education about the consumption of vegetables and fruits in all school-aged children and parents of school-age children in all grades.

Keywords: vegetables and fruits, school-aged children, obesity, health education, behavior.

\section{PENDAHULUAN}

Obesitas merupakan salah satu masalah kesehatan yang terjadi di Indonesia. Kasus obesitas terjadi pada semua kelompok umur dan pada semua strata sosial ekonomi. Kejadian obesitas pada anak merupakan masalah serius karena dapat berlanjut sampai usia dewasa. Kejadian obesitas pada anak merupakan salah satu faktor penyakit metabolik dan degeneratif seperti penyakit kardiovaskuler, diabetes mellitus, kanker dan osteoartritis. Obesitas pada anak dapat mengakibatkan gangguan pertumbuhan tungkai kaki, gangguan tidur, sleep apnea (henti napas sesaat) dan gangguan pernapasan lain (Kemenkes, 2012). Saat ini terjadi perubahan paradigma terkait masalah gizi, yang dulunya tentang gizi kurang saat ini menjadi kecukupan gizi bahkan sebagian besar anak- anak mengalami gizi berlebih. Masalah gizi berlebih atau lebih dikenal dengan istilah obesitas. Penelitian yang dilakukan di beberapa negara di Indonesia, kejadian obesitas pada anak sangat tinggi.

Hasil Riskesdas tahun 2010 menunjukkan prevalensi obesitas pada anak sekolah (6-12 tahun) sebesar 9,2\%. Sebelas propinsi, seperti D.I. Aceh (11,6\%), Sumatera Utara (10,5\%), Sumatera Selatan $(11,4 \%)$, Riau (10,9\%), Lampung (11,6\%), Kepulauan Riau (9,7\%), DKI Jakarta (12,8\%), Jawa Tengah (10,9\%), Jawa Timur (12,4\%), Sulawesi Tenggara (14,7\%), Papua Barat $(14,4 \%)$ berada di atas prevalensi nasional (Kemenkes, 2012). Hasil penelitian di beberapa kota juga menunjukkan bahwa ada kecenderungan peningkatan prevalensi kegemukan dan obesitas pada anak. Studi prevalensi di Sekolah Dasar kawasan Jakarta timur berjumlah 27.5\%, serta 35\% mempunyai kasus obesitas ditemukan di poliklinik Gizi Anak Bagian Ilmu Kesehatan Anak RSCM Jakarta periode 1995-2000. Prevalensi kegemukan dan obesitas pada anak sekolah di Yogyakarta pada tahun 1999 sebesar 8,0\% meningkat menjadi 12,3\% pada tahun 2004 (Kemenkes, 2012). Data dari Pediatric Academic Society tahun 2000 lebih dari sembilan juta anak di dunia berusia enam tahun keatas mengalami obesitas. Hasil penelitian di Amerika Serikat 31,2\% anak berusia 6-11 tahun kelebihan berat badan dan $15.8 \%$ mengalami obesitas, sedangkan pada remaja (12-19 tahun) $30.9 \%$ kelebihan berat badan, yang mana 16,1\% obesitas (Katier et al., 2008).

Obesitas kemungkinan disebabkan oleh faktor lingkungan terutama terjadi karena ketidakseimbangan antara pola makan, perilaku makan dan aktivitas fisik. Hal ini terutama berkaitan dengan perubahan gaya hidup yang mengarah pada sedentary life style (Kemenkes, 2012). Selain itu faktor genetik diduga juga memiliki peran, tetapi faktor ini tidak dapat menjelaskan terjadinya peningkatan prevalensi kegemukan dan obesitas pada anak (Sartika, 2011). Anak usia sekolah sudah pandai memilih makanan yang mereka sukai, mereka lebih senang mengkonsumsi makanan instan yang banyak mengandung karbohidrat dan vetsin serta penyedap rasa. Mereka lebih menyukai makanan cepat saji dan rendah serat, rendah vitamin dan rendah mineral, tapi tinggi kalori, tinggi lemak, serta tinggi garam natrium, sehingga menyebabkan obesitas. Selain itu menurut Kronel (2011) rasa merupakan alasan utama anak tidak mengonsumsi sayur dan buah, ketersediaan dan akses sayur dan buah mempengaruhi pola konsumsi anak.

Pola konsumsi anak usia sekolah terjadi dari kebiasaan makan, serta perasaan suka dan tidak suka terhadap makanan. Anak cenderung menyukai makanan cepat saji dengan alasan lebih enak dan mengenyangkan. Hal ini menyebabkan konsumsi buah dan sayur pada anak cenderung rendah (Hayati, 2009). Konsumsi buah dan sayur yang kurang pada masyarakat di Indonesia ditunjukkan oleh data dari Riset Kesehatan Dasar (Riskesdas) 2013 bahwa kecenderungan proporsi penduduk umur $>10$ tahun yang mengonsumsi kurang sayur dan buah. Buah dan sayur dapat menurunkan 
risiko obesitas pada anak, karena buah dan sayur mampu membakar lemak tanpa menambah banyak kalori. Oleh sebab itu diperlukan upaya untuk meningkatkan perilaku konsumsi sayur dan buah pada anak melalui pendidikan kesehatan sebagai upaya pencegahan obesitas pada anak sekolah.

\section{METODE PELAKSANAAN}

Program pengabdian kepada masyarakat dilaksanakan di SDN Mulyorejo 1 Surabaya Jawa Timur. Sasaran peserta adalah orang tua murid kelas 3. Jumlah peserta yang hadir adalah 28 orang. Program ini menggunakan metode pembelajaran dari tim Departemen Keperawatan Anak dan Maternitas Fakultas Keperawatan Universitas Airlangga. Sebelum program ini laksanakan orang tua di beri pre test untuk mengetahui tingkat pengetahuan orang tua tentang konsumsi buah dan sayur dengan obesitas pada anak. Setelah pre test dilanjutkan dengan pemberian program pendidikan (informasi dan keterampilan) melalui metode ceramah, diskusi, demonstrasi dan redemostrasi. Bentuk evaluasi terhadap pengetahuan orang tua melalui post test dan tindakan melalui praktik pemilihan dan penyediaan menu makanan sayur dan buah untuk anak.

\section{HASIL DAN PEMBAHASAN}

\subsection{Hasil}

Data demografi peserta yang ditunjukkan pada tabel 3.1 menunjukkan bahwa usia peserta sebagian besar pada rentang 31-40 tahun sebanyak 23 orang $(82,1 \%)$. Usia peserta masuk dalam kategori perkembangan usia dewasa muda. Pendidikan peserta sebagian besar SMU/SLTA sebanyak 22 orang $(78,6 \%)$. Pekerjaan peserta sebagian besar adalah ibu rumah tangga sebanyak 22 orang $(78,6 \%)$. Jenis kelamin peserta sebagian besar adalah perempuan atau ibu yaitu sebesar 24 orang $(85,7 \%)$.

Tabel 3.1 Distribusi frekuensi data demografi peserta peningkatan perilaku konsumsi sayur dan buah sebagai upaya pencegahan obesitas pada anak Oktober 2017

\begin{tabular}{|c|l|c|c|}
\hline No & Data Demografi & f & \% \\
\hline \multirow{4}{*}{2} & Usia & & 17,9 \\
\cline { 2 - 4 } & $20-30$ tahun & 5 & 82,1 \\
\cline { 2 - 4 } & $31-40$ tahun & 23 & 3,6 \\
\hline \multirow{4}{*}{2} & Pendidikan & 1 & 10,7 \\
\cline { 2 - 4 } & SD & 3 & 78,6 \\
\cline { 2 - 4 } & SMP & 22 & 7,1 \\
\cline { 2 - 4 } & SMU/SLTA & 2 & \\
\cline { 2 - 4 } & Sarjana & & 78,6 \\
\hline 3 & Pekerjaan & 22 & 7,1 \\
\cline { 2 - 4 } & Ibu rumah tangga & 2 & 14,3 \\
\cline { 2 - 4 } & PNS & 4 & 14,3 \\
\cline { 2 - 4 } & Wiraswasta & & 85.7 \\
\hline \multirow{3}{*}{4} & Jenis kelamin anak & 24 & \\
\cline { 2 - 4 } & Laki-laki & & \\
\cline { 2 - 4 } & Perempuan & & \\
\hline
\end{tabular}

Data tingkat pengetahuan peserta yang ditunjukkan pada tabel 3.1 menunjukkan bahwa ada peningkatan tingkat pengetahuan antara sebelum dan sesudah dilakukan pendidikan kesehatan. Terjadi peningkatan pengetahuan baik dari 17 orang $(60,7 \%)$ menjadi 27 orang $(96,4 \%)$. 
Tabel 3.2 Distribusi pengetahuan peserta peningkatan perilaku konsumsi sayur dan buah sebagai upaya pencegahan obesitas pada anak Oktober 2017

\begin{tabular}{|c|l|c|c|c|c|}
\hline No & Tingkat Pengetahuan & \multicolumn{2}{c|}{$\begin{array}{c}\text { Pre test } \\
(\mathrm{n}=28)\end{array}$} & \multicolumn{2}{c|}{$\begin{array}{c}\text { Post test } \\
(\mathrm{n}=28)\end{array}$} \\
\cline { 3 - 6 } & & $\mathrm{n}$ & $\%$ & $\mathrm{n}$ & $\%$ \\
\hline 1 & Baik & 17 & 60,7 & 27 & 96,4 \\
\hline 2 & Cukup & 10 & 35,7 & 1 & 3,6 \\
\hline 3. & Kurang & 1 & 3,6 & 0 & 0 \\
\hline
\end{tabular}

\subsection{Pembahasan}

Menurut Notoatmojo (2010), pengetahuan mempunyai enam tingkatan yaitu; tahu, memahami, aplikasi, analisis (menjabarkan materi), sintesis dan evaluasi/ melakukan justifikasi. Pendidikan kesehatan merupakan proses belajar dari individu, kelompok, masyarakat dari tidak tahu nilai-nilai kesehatan menjadi tahu, dari tidak mampu mengatasi masalah kesehatan menjadi mampu.

Hasil pre test pengetahuan yang dinilai sebelum pemberian pendidikan kesehatan didapatkan 60,7\% dalam kategori baik, 35,7\% kategori cukup, dan 3,6\% kategori kurang. Hasil post test pengetahuan didapatkan hampir seluruh peserta dalam kategori baik. Menurut Notoatmodjo (2010) pengetahuan dipengaruhi oleh faktor internal dan eksternal. Peningkatan pengetahuan peserta tentang konsumsi sayur dan buah secara internal dapat dipengaruhi oleh usia yang akan mempengaruhi kemampuan untuk menerima informasi. Peserta sebagian besar berada pada tahap usia dewasa muda yang memiliki kematangan dalam daya pikir. Tingkat pendidikan peserta yang tinggi sehingga mudah untuk memahami dan menerima informasi baru. Faktor lingkungan juga mempengaruhi penyampaian informasi dari pendidik kepada peserta didik. Lingkungan dapat juga berdasarkan tempat kerja, lingkungan kerja dapat mendukung seseorang untuk mendapatkan informasi. Selain itu faktor eskternal misal lingkungan tempat informasi disampaikan, lingkungan yang kurang mendukung dapat membaurkan informasi.

Pemilihan metode pendidikan kesehatan merupakan faktor yang penting dalam menilai keberhasilan penyampaian informasi. Metode ceramah adalah penyampaian informasi kepada peserta secara lisan Notoatmodjo (2010). Diskusi adalah pembahasan suatu topik atau materi oleh tiga orag atau lebih dan dipandu oleh seorang pemimpin. Demonstrasi adalah metode pembelajaran yang menyajikan suatu prosedur atau tugas, cara menggunakan alat, dan cara berinteraksi. Demonstrasi dapat dilakukan secara langsung atau melalui media seperti video dan film. Pelaksanaan metode pembelajaran ceramah dan diskusi akan meningkatkan proses penerimaan pengetahuan atau informasi. Metode demonstrasi memiliki kelebihan juga yaitu penyampaian lebih menarik dan jelas, menghindari faktor verbalisme dan juga bisa memfasilitasi seseorang untuk menerapkan teori dalam kenyataan. Pada kegiatan ini peserta mengalami peningkatan pengetahuan signifikan dari sebelum dan sesudah pelaksanaan pelatihan. Selain itu memiliki keterampilan pada kemampuan pemilihan sayur dan buah serta penyiapan makanan yang sehat untuk anak usia sekolah.

\section{KESIMPULAN DAN SARAN}

\subsection{Kesimpulan}

Program pendidikan meningkatkan pengetahuan orang tua tentang konsumsi sayur dan buah untuk anak. Selain itu meningkatkan praktik atau keterampilan orang tua dalam penyiapkan makanan sehat bagi anak yang mengandung sayur dan buah. 


\subsection{Saran}

Tindak lanjut dari program pengabdian kepada masyarakat ini adalah pemberian edukasi konsumsi sayur dan buah disampaikan ke semua orang tua murid Sekolah Dasar. Edukasi diberikan juga kepada anak usia sekolah sebagai upaya untuk meningkatkan pengetahuan dan pemahaman anak tentang manfaat sayur dan buah dengan metode pembelajaran yang sesuai. Sekolah sebagai wahana Pendidikan dapat mengelola kantin sekolah dengan menyediakan makanan yang memiliki unsur sayur dan buah.

\section{UCAPAN TERIMAKASIH}

Program Pengabdian Kepada Masyarakat ini dapat terwujud atas bantuan dan peran serta dari berbagai pihak, perkenankanlah kami menyampaikan terima kasih kepada Rektor Universitas Airlangga, Ketua LP4M Universitas Airlangga, Dekan Fakultas Keperawatan Universitas Airlangga, Kepala Sekolah SDN Mulyorejo 1 Surabaya, orang tua murid kelas 3 SDN Mulyorejo 1 Surabaya dan semua tim program pengabdian kepada masyarakat.

\section{DAFTAR PUSTAKA}

Hayati, N (2009). Faktor-faktor Perilaku yang Berhubungan dengan Kejadian Obesitas di Kelas 4 dan 5 SD Pembangunan Jaya Bintaro Tangerang Selatan Tahun 2009. Skripsi. FKM UI

Katier, et al (2008). Early Cardiac Abnormalities in Obese Children: Importance of Obesity per se Versus Associated Cardiovascular Risk Factor. Pediatric Research 64(2): 205-209

Kemenkes (2012). Pencegahan dan Penanggulangan Kegemukan dan Obesitas pada Anak Sekolah. Jakarta Kementrian Kesehatan RI

Kronel, R. et al (2011). Determinants of Fruit and Vegetable Consumption among Children and Adolescents: A Review of Literature. Part II: Qualitative Study. International Journal of Behavioral Nutrition and Physical Activity, 8(112)

Nuraeni, I , H. Hadi and Y. Paratmaniya (2013). Perbedaan Konsumsi Buah dan Sayur pada Anak Sekolah Dasar yang Obes dan Tidak Obes di Kota Yogyakarta dan Kabupaten Bantul. Jurnal Gizi dan Dietetik Indonesia. Vol. 1 No.2, 81-92

Notoatmodjo, (2010). Ilmu Perilaku Kesehatan. Rineka Cipta

Sartika, R.A.D., (2011). Faktor Risiko Obesitas pada Anak 5-15 Tahun di Indonesia. Jurnal Makara Kesehatan. 15: 37-43 